\title{
Open access muuttaa tiedeseuraa
}

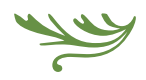

Tiedelehdet siirtyvät verkon avoimiin julkaisuympäristöihin. Mitä murroksesta ajatellaan tiedeseuroissa, joille määräajoin postilaatikosta kolahtava lehti on ollut tärkeä jäsenhoukutin?
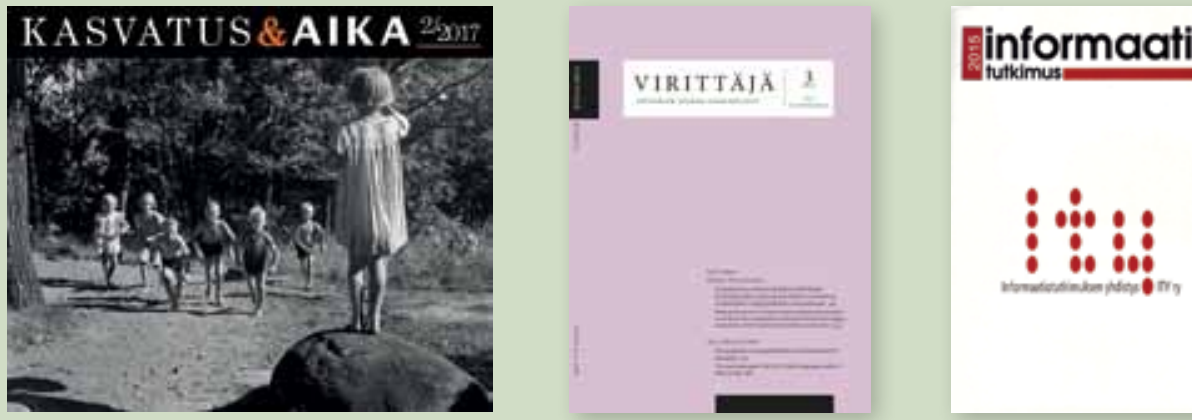


\section{INFORMAATIOTUTKIMUS "Vaikuttavuus lisääntyi, jäsenmäärä ei"}

Informaatiotutkimuksen yhdistys julkaisee vertaisarvioitua Informaatiotutkimusta avoimesti verkossa. Seuran jäsenkunta koostuu alan tutkijoista ja opettajista, opiskelijoista sekä kirjastonhoitajista ja informaatikoista.

SIIRRYIMME AVOIMEEN verkkojulkaisemiseen vuonna 2008. Luovuimme painetusta lehdestä, mutta painatamme verkkojulkaisun artikkeleista vuosikirjan.

Ensimmäisen verkossa julkaistun lehden pääkirjoituksessa tuolloinen päätoimittaja Kai Halttunen kirjoitti että "Haluamme tarjota lukijoillemme ja kirjoittajille sekä digitaalisen palvelun joustavuutta sekä painetun julkaisun pysyvyyttä ja kokonaisuuden hahmottamista tukevaa lukutapaa”. Avoimuus ja maksuttomuus ovat olleet yhdistyksen tärkeitä arvoja, ja avoin verkkojulkaiseminen vastaa niitä.

Lehden koko aineisto, vuodesta 1981, on digitoitu ja avoimesti saatavilla.

Avoimen julkaisemisen ansiosta lehti tavoittaa aiempaa laajemman lukija- ja kirjoittajakunnan. Si- ten sen vaikuttavuus on lisääntynyt. Samoin on käynyt aineistotarjonnalle ja kävijämäärälle. Lukijakunta on varsin laaja etenkin, kun otetaan huomioon, että tieteenalamme on pieni.

Samanaikaisesti yhdistyksen jäsenmäärä on kuitenkin laskenut, kun merkittävä jäsenetu, painettu lehti, on menettänyt merkitystään.

Kun luovuimme painetusta lehdestä, informaatiotutkimuksen yliopistokoulutusta tarjoavat yksiköt sitoutuivat tukemaan verkkojulkaisua taloudellisesti. Lisäksi julkaisemisen mahdollistavat Informaatiotutkimuksen yhdistyksen jäsenmaksut ja TSV:n kautta ohjautuva opetus- ja kulttuuriministeriön tuki.

Silti julkaisua tehdään pitkälti talkoovoimin. Pohdimme keinoja, joilla toimitustyötä tekevät saisivat työstään asianmukaisen korvauksen. Olemme ilmaisseet halukkuutemme olla mukana Kotilavahankkeessa.

Nykyisen päätoimittajan Susanna Nykyrin ja toimitussihteeri Matti Lassilan aikana on panostettu lehden tekniseen kehitystyöhön. Käytössämme 


\section{RATKAISUJA ON HAETTAVA}

LAAJALLA YHTEISTYÖLL $\ddot{A}$.

on OJS-versio ja pdf-muodon rinnalla on xml-rikasteinen julkaiseminen. Toimitusprosesseja ja toimituskunnan muodostusperiaatteita on uudistettu.

Lehden haasteena ovat yhä rahoituspohja ja etenkin artikkelikäsikirjoituksissa kansainvälinen kilpailu ja englanninkielisen julkaisemisen volyymi. Ratkaisuja on haettava laajalla yhteistyöllä. Kotimainen julkaisukanava voi toimia kansainvälisesti, mutta se vaatii tietoista kehittämistä ja kentän tukea.

Suomen tiedekustantajat ja TSV järjestävät koulutuksia, jotka tarjoavat samalla tarpeellisen verkostoitumismahdollisuuden. Yhteistyö toteutuu verkostoissa: se on kokemusten ja parhaiden käytäntöjen pohdintaa sekä selvitysten ideointia ja alullepanoa.

\section{Termit tutuiksi}

Avoin tiede ja tutkimus on opetus- ja kulttuuriministeriön hanke, jolla edistetään tiedon saatavuutta ja avointa tiedettä. Käytännössä se tarkoittaa, että pääasiassa tiedeseurojen julkaisemat painetut tiedelehdet siirtyvät verkkoon.

Avoimia, maksuttomia verkkojulkaisuja kutsutaan open access -julkaisuiksi.

Lisää aiheesta: https://avointiede.fi

Kotilava eli Kotimaiset lehdet avoimiksi ja vaikuttamaan on Tieteellisten seurain valtuuskunnan (TSV) ja Kansalliskirjaston hanke. Siinä ratkotaan open access -julkaisemisen rahoitusta ja tekniikkaa.

Pyrkimys on luoda lehdille avoimen julkaisemisen mahdollistava rahoitusmalli ja kehittää kustannustehokas tekninen alusta.

Lisää aiheesta: www.kotilava.fi.

\section{TERVEISET AIKUISKASVATUKSELLE}

Avoin julkaiseminen on paitsi rahoittajien yleinen vaatimus myös tutkijoiden tahtotila. Uskomme, että lehden elinvoima on sidoksissa sen avoimeen saatavuuteen.

Tutustu julkaisuun: https://journal.fi/inf/index

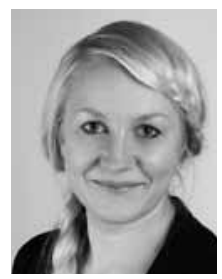

NOORA HIRVONEN

puheenjohtaja

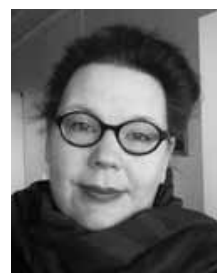

SUSANNA NYKYRI

päätoimittaja
Journal.fi on tiedelehtien toimittamiseen ja julkaisemiseen tarkoitettu palvelu, jota pitää yllä TSV.

Sivustolla on nelisenkymmentä suomalaista tieteellistä lehteä ja vuosikirjaa. Palvelu käyttää Open Journal System (OJS) 3.0 -ohjelmistoa.

Lisää aiheesta: https://journal.fi

Tieteellisten seurain valtuuskunta (TSV) on riippumaton, tieteenharjoittamista ja tiedepolitiikkaa koskevien asioiden asiantuntijaelin.

Se edistää tiedeseurojen yhteistyötä, tiedeviestintää ja tutkimustiedon hyödyntämistä yhteiskunnassa. Se jakaa valtionavustuksia tiedeseurojen julkaisutoimintaan, kansainväliseen toimintaan ja tieteellisten konferenssien järjestämiseen.

Lisää aiheesta: https://www.tsv.fi 